\title{
IUCN guidelines using for assessment of plants from the Red Book of Russian Federation at regional level: a case study for the Republic of Mordovia (Russia)
}

\author{
Anatoliy A. Khapugin ${ }^{1,2, *}$, Tatyana B. Silaeva ${ }^{2}$, Elena V. Vargot ${ }^{1,2,3}$ \& \\ Gennadiy G. Chugunov ${ }^{1,2,3}$
}

Key words: IUCN, assessment, Red Data Book, endangered species, threat status, area of occupancy, extent of occurrence, Mordovia.

Ključne besede: IUCN, ocena, rdeči seznam, ogrožene vrste, status ogroženosti, območje celotne razširjenosti, območje dejanske razširjenosti, Mordovia.
Received: 17.1.2016

Revision received: 27.3. 2016

Accepted: 31. 3. 2016

\begin{abstract}
There are 15 plant species included in the Russian Red Book, which occur in the Republic of Mordovia: Najas tenuissima, Koeleria sclerophylla, Stipa dasyphylla, S. pennata, S. pulcherrima, S. zalesskii, Fritillaria ruthenica, Iris aphylla, Cypripedium calceolus, Cephalanthera rubra, Epipogium aphyllum, Neottianthe cucullata, Orchis militaris, Neotinea ustulata, Thymus cimicinus. Of these, only C. calceolus is included in the Global Red List as Critically Endangered. Threat status for studied species in Mordovia was assessed, and their distribution dynamics in this region throughout 12 years was described. Recent floristic studies, inspections of herbariums and literature were used for searches all provided data. Grid mapping and IUCN criteria were used. Nine taxa were determined as Critically Endangered, three as Endangered, one as Vulnerable, one as Near Threatened and one as Data Deficient. The areas of occupancy and extent of occurrence in Mordovia were assessed for each taxon. All studied species should be included in the next edition of the Mordovian Red Book. F. ruthenica, E. aphyllum, N. ustulata, T. cimicinus require additional studies to confirm earlier observations.
\end{abstract}

\begin{abstract}
Izvleček
Petnajst rastlinskih vrst, ki uspevajo v republiki Mordoviji, je vključenih v rdeči seznam Rusije: Najas tenuissima, Koeleria sclerophylla, Stipa dasyphylla, Stipa pennata, Stipa pulcherrima, Stipa zalesskii, Fritillaria ruthenica, Iris aphylla, Cypripedium calceolus, Cephalanthera rubra, Epipogium aphyllum, Neottianthe cucullata, Orchis militaris, Neotinea ustulata, Thymus cimicinus. Med njimi je le C. calceolus vključena tudi v globalni rdeči seznam kot skrajno ogrožena vrsta. Za naštete vrste smo ocenili status ogroženosti in njihovo dinamiko razširjenosti $\mathrm{v}$ tej regiji v zadnjih 12 letih. Za predstavljene podatke smo uporabili nedavne floristične raziskave, preglede herbarijskih zbirk in literaturo. Uporabili smo metodo kartiranja kvadrantov in kriterije IUCN. Devet taksonov smo ocenili kot skrajno ogrožene, tri kot ogrožene, enega kot ranljivo vrsto, enega kot potencialno ogroženega in enega kot vrsto za katero obstaja premalo podatkov. Za vsak takson smo določili območje celotne in dejanske razširjenosti. Vse obravnavane vrste je potrebno vključiti v naslednjo izdajo rdečega seznama Mordovije. Za vrste Fritillaria ruthenica, Epipogium aphyllum, Neotinea ustulata, Thymus cimicinus so potrebne dodatne raziskave, ki bi potrdile prejšnja opažanja.
\end{abstract}

1 Mordovia State Nature Reserve, 431230, Pushta, Temnikov district, Republic of Mordovia, Russian Federation. E-mail: hapugin88@yandex.ru

2 Department of Botany, Physiology and Ecology of Plants, Mordovia State University, Bolshevistskaya Street, 68, 430005, Saransk, Republic of Mordovia, Russian Federation.

3 National Park "Smolny”, Topoley Street, 11, 431660, Smolny, Ichalki district, Republic of Mordovia, Russian Federation.

* Corresponding author 


\section{Introduction}

The Republic of Mordovia is located on the border of the forest and forest-steppe zones in the Middle Volga. Eastern Mordovia covers the north-west of the Volga Upland, but the western region is located on the Oka-Don Lowland. Therefore considerable diversity of habitats is observed within this area. Coniferous and mixed forests are distributed in the west, north-west and north of Mordovia. Broad-leaved forests are located in the central and eastern parts. Forest-steppe landscapes dominate in the east and south-east of Mordovia (Yamashkin 1998, 2012).

Steppe vegetation elements occur on a small number of "islands" of land useless for agriculture (e.g. on the slopes of ravines, on hills and on banks in the river valleys). Steppe areas may be more common due to vegetation overgrowth on sedimentary deposits, especially near steep slopes covered by steppe formations. This is associated with a reduction of grazing impact. On the slopes, this mainly results from mesophytic grasses. These areas are usually colonized by shrubs and trees (Khapugin \& Silaeva 2013). Additionally, the forest area is increasing due to reforestation on abandoned lands adjacent to woodland (Mather 2001). Primarily, this concerns pine and birch forests.

The flora of the Republic of Mordovia includes 1430 species of vascular plants (Silaeva et al. 2010a, Khapugin 2012, Vargot et al. 2012, Khapugin 2013, Khapugin \& Buzunova 2013, Chkalov \& Pakina 2014, Maevskiy 2014). Among them, 170 vascular plant species were included to the regional Red Data Book (hereafter also referred to as RBRM) (Silaeva 2003). Twelve years have passed since the publication of "Red Data Book of the Republic of Mordovia" (Silaeva 2003). Throughout this time, results of research of rare plants have been published annually (Silaeva et al. 2004, 2005, 2006, 2007 ,
2008, 2009, 2010b, 2011, 2012, 2013, 2014, 2015). They include information about new findings of rare species in the Republic of Mordovia and about plants that have been recommended for inclusion to the regional Red Data Book for the first time.

Due to intensive floristic studies in the Republic of Mordovia, a significant number of new or unpublished data on population sizes, distributions and the habitat conditions of endangered plant species in Mordovia was collected. Among them, plant species included to the Russian Red Book (hereafter referred to as RBRF) (Bardunov \& Novikov 2008) have a special importance (Table 1). Of these, two species were found in Mordovia in recent years: Najas tenuissima (A. Braun ex Magnus) Magnus (Silaeva et al. 2014) and Koeleria sclerophylla P.A. Smirn. (Maevskiy 2014).

Only a small percentage of populations of the plant species studied are located within the existing network of protected areas of Mordovia (see Table 2). Most of them are located in (or outside) the places recommended for the establishment of protected areas. Long-term monitoring of populations is required to determine their status and the risk extinction for them. For example, Najas tenuissima micropopulations are monitored within the protected areas of the Nizhny Novgorod region (Protected Area Filippovskie prudy [Filippov's ponds]).

There are few published works in Russia which are devoted to the assessment of plant taxa according to IUCN criteria and categories (Blinova \& Uotila 2011). Few regional Red Books contain information on the threatened status of rare plant species (Konstantinova et al. 2003, 2014, Chernyagina 2007). The assessment of taxa in different regions of Russia according to the IUCN criteria will allow better assessments of their overall status within the country. In contrast with Russia, similar works for the assessment and analysis of Red Lists are numerous in Europe, and they are the basis of environmental

Table 1: Number of plant species included in the Red Data Book of the Russian Federation, which occur in the Republic of Mordovia. Tabela 1: Število rastlinskih vrst, vključenih v rdeči seznam Ruske federacije, ki se pojavljajo na ozemlju republike Mordovije.

\begin{tabular}{lccc} 
Family & $\begin{array}{c}\text { Total number of species } \\
\text { included in RBRF } \\
\text { per family }\end{array}$ & $\begin{array}{c}\text { Number of species included } \\
\text { in RBRF, which occur in the } \\
\text { Republic of Mordovia. }\end{array}$ & $\begin{array}{c}\text { Percentage of the number of species included } \\
\text { in RBRF, which occur in Mordovia to the total } \\
\text { number of species included in RBRF, \% }\end{array}$ \\
\hline $\begin{array}{l}\text { Orchidaceae } \\
\text { Poaceae }\end{array}$ & 65 & 6 & 9.2 \\
Najadaceae & 20 & 5 & 25.0 \\
Liliacaeae & 2 & 1 & 50.0 \\
Iridaceae & 17 & 1 & 5.9 \\
Lamiaceae & 17 & 1 & 5.9 \\
Other families & 4 & 1 & 25.0 \\
Total: & 389 & - & - \\
\hline
\end{tabular}


Table 2: Number of populations located within (or outside) the Protected Areas in Mordovia (Kuznetsov \& Silaeva 2008) and the Nizhny Novgorod region (Bakka \& Kiseleva 2008).

Tabela 2: Število populacij v (ali izven) zavarovanih območij v Mordoviji (Kuznetsov \& Silaeva 2008) in regiji Nizhny Novgorod (Bakka \& Kiseleva 2008).

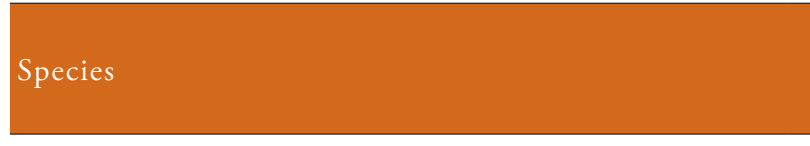

Najas tenuissima (A. Braun ex Magnus) Magnus

Koeleria sclerophylla P.A. Smirn.

Stipa dasyphylla (Lindem.) Czern. ex Trautv.

Stipa pennata L.

Stipa pulcherrima K. Koch

Stipa zalesskii Wilensky

Fritillaria ruthenica Wikst.

Iris aphylla L.

Cypripedium calceolus $\mathrm{L}$.

Cephalanthera rubra (L.) Rich

Epipogium aphyllum $\mathrm{Sw}$.

Neottianthe cucullata (L.) Schltr.

Orchis militaris L.

Neotinea ustulata (L.) R.M. Bateman, Pridgeon \& M.W. Chase

Thymus cimicinus Blume ex Ledeb.
Rarity category

consistent with RBRM
Number of populations located within the Protected Areas to the total number of populations in Mordovia for each species management (Tomović et al. 2007, 2009, Eliáš jun. et al. 2015, Rossi et al. 2015, Stroh et al. 2014, Moreno Saiz et al. 2015, etc.).

Grid mapping has little value for mapping the distributions of Russian plant taxa. There are only five such works: "Flora of the Central Siberia" (Malyshev \& Peshkova 1979); "Atlas of waterbodies flora of Tula region" (Shcherbakov 1999); "Orchids of north-west European part of Russia” (Efimov 2012); "Preliminary results of grid mapping of flora of Udomlya district of Tver region" (Abramova et al. 2011) and the largest "Flora of Vladimir Oblast, Russia: checklist and atlas" (Seregin 2012). Seregin (2014) has published a guide to the analysis of the results of grid mapping of plant taxa: "Flora of Vladimir Oblast, Russia: grid data analysis". Thus, this paper is one of the first works in Russia that combines both grid mapping and the use of IUCN criteria to plant taxa at a regional level.

The aim of this paper is to show the current state of chorological data for plant species included in the Russian Red Book (Bardunov \& Novikov 2008) which are also known from Mordovia, 12 years after the regional Red Book (Silaeva 2003) had been published. Based on these data, we have assessed the threatened status of these plant taxa, according to IUCN Criteria and Categories (2012a, 2012b, 2014).

\section{Material and methods}

Results are a part of a series of intensive floristic and chorological studies of rare Mordovian taxa. Field survey, checking and revision of herbarium material and numerous literature sources were used to supplement the distribution records. The nomenclature and the taxonomy of the investigated plant taxa are presented consistent with The Plant List (2013) and Euro + Med Plantbase (Euro + Med 2006+) taking into account data of Maevskiy (2014).

The distributions of rare plant species in the Republic of Mordovia was mapped by Grishutkin (2013), with a few modifications. Basic cells size was 5 ' in latitude and 10' in longitude (approximately $9.2 \times 10.4 \mathrm{~km}$ ). Each major grid cell (e.g. a cell between parallels $54^{\circ}$ and $55^{\circ}$ and between meridians $45^{\circ}$ and $46^{\circ}$ ) was divided into 72 basic cells, and named according to the structure "latitude/longitude-number of this basic cell within divided major grid cell", for example, 54/44-14 (Figure 1). Border areas of Mordovia less than 10 square kilometers have not been separated to individual basic cells, consistent with Seregin (2014). The few records of plant species in these small areas have been attributed to adjacent cells. 


\begin{tabular}{|c|c|c|c|c|c|c|c|c|c|c|c|c|c|c|c|c|c|}
\hline 54/43-1 & $54 / 43-2$ & $54 / 43-3$ & 54/43-4 & 54/43-5 & 54/43-6 & $54 / 44-1$ & $54 / 44-2$ & $54 / 44-3$ & $54 / 44-4$ & $54 / 44-5$ & $54 / 44-6$ & $54 / 45-1$ & $54 / 45-2$ & $54 / 45-3$ & $54 / 45-4$ & $54 / 45-5$ & $54 / 45-6$ \\
\hline $54 / 43-7$ & 54/43-8 & $54 / 43-9$ & 54/43-10 & 54/43-11 & $54 / 43-12$ & $54 / 44-7$ & $54 / 44-8$ & $54 / 44-9$ & $54 / 44-10$ & 54/44-11 & 54/44-12 & $54 / 45-7$ & $54 / 45-8$ & $54 / 45-9$ & $54 / 45-10$ & $54 / 45-11$ & $54 / 45-12$ \\
\hline $54 / 43-13$ & 54/43-14 & $54 / 43-15$ & 54/43-16 & $54 / 43-17$ & $54 / 43-18$ & $54 / 44-13$ & $54 / 44-14$ & $54 / 44-15$ & $54 / 44-16$ & $54 / 44-17$ & $54 / 44-18$ & $54 / 45-13$ & $54 / 45-14$ & $54 / 45-15$ & $54 / 45-16$ & $54 / 45-17$ & $54 / 45-18$ \\
\hline $54 / 43-25$ & 54/43-26 & $54 / 43-27$ & 54/43-28 & 54/43-29 & $54 / 43-30$ & $54 / 44-25$ & $54 / 44-26$ & $54 / 44-27$ & $54 / 44-28$ & $54 / 44-29$ & $54 / 44-30$ & $54 / 45-25$ & $54 / 45-26$ & $54 / 45-27$ & $54 / 45-28$ & $54 / 45-29$ & $54 / 45-30$ \\
\hline $54 / 43-31$ & 54/43-32 & 54/43-33 & 54/43-34 & 54/43-35 & $54 / 43-36$ & $54 / 44-31$ & 54/44-32 & $54 / 44-33$ & 54/44-34 & $54 / 44-35$ & $54 / 44-36$ & 54/45-31 & $54 / 45-32$ & 54/45-33 & $54 / 45-34$ & $54 / 45-35$ & $54 / 45-36$ \\
\hline $54 / 43-37$ & $54 / 43-38$ & 54/43-39 & $54 / 43-40$ & 54/43-41 & $54 / 43-42$ & $54 / 44-37$ & $54 / 44-38$ & 54/44-39 & $54 / 44-40$ & 54/44-41 & $54 / 44-42$ & 54/45-37 & $54 / 45-38$ & 54/45-39 & $54 / 45-40$ & $54 / 45-41$ & $54 / 45-42$ \\
\hline $54 / 43-43$ & 54/43-44 & $54 / 43-45$ & $54 / 43-46$ & $54 / 43-47$ & $54 / 43-48$ & $54 / 44-43$ & 54/44-44 & $54 / 44-45$ & $54 / 44-46$ & $54 / 44-47$ & $54 / 44-48$ & $54 / 45-43$ & $54 / 45-44$ & $54 / 45-45$ & $54 / 45-46$ & $54 / 45-47$ & $54 / 45-48$ \\
\hline $54 / 43-49$ & 54/43-50 & 54/43-51 & 54/43-52 & $54 / 43-53$ & $54 / 43-54$ & $54 / 44-49$ & $54 / 44-50$ & $54 / 44-51$ & $54 / 44-52$ & $54 / 44-53$ & $54 / 44-54$ & $54 / 45-49$ & $54 / 45-50$ & $54 / 45-51$ & $54 / 45-52$ & $54 / 45-53$ & $54 / 45-54$ \\
\hline $54 / 43-55$ & 54/43-56 & 54/43-57 & 54/43-58 & 54/43-59 & $54 / 43-60$ & $54 / 44-55$ & $54 / 44-56$ & $54 / 44-57$ & $54 / 44-58$ & $54 / 44-59$ & $54 / 44-60$ & 54/45-55 & $54 / 45-56$ & $54 / 45-57$ & $54 / 45-58$ & $54 / 45-59$ & $54 / 45-60$ \\
\hline $54 / 43-61$ & 54/43-62 & 54/43-63 & 54/43-64 & $54 / 43-65$ & $54 / 43-66$ & $54 / 44-61$ & 54/44-62 & $54 / 44-63$ & $54 / 44-64$ & $54 / 44-65$ & $54 / 44-66$ & $54 / 45-61$ & $54 / 45-52$ & $54 / 45-63$ & $54 / 45-64$ & $54 / 45-65$ & $54 / 45-66$ \\
\hline $54 / 43-67$ & 54/43-68 & $54 / 43-69$ & $54 / 43-70$ & 54/43-71 & $54 / 43-72$ & $54 / 44-67$ & 54/44-68 & $54 / 44-69$ & $54 / 44-70$ & 54/44-71 & $54 / 44-72$ & 54/45-67 & $54 / 45-68$ & $54 / 45-69$ & $54 / 45-70$ & $54 / 45-71$ & $54 / 45-72$ \\
\hline
\end{tabular}

Figure 1: The scheme of indices of grid cells for plant taxa mapping in Mordovia.

Slika 1: Shema oznak kvadrantov za kartiranje flore v Mordoviji.

Collected material of plant species is deposited in the Herbarium of the Moscow State University, Moscow (MW), the Herbarium of the Botanical Institute RAS, Saint-Petersburg (LE), the Herbarium of the Mordovia State University, Saransk (GMU), the Herbarium of the Penza Pedagogical University (PKM) and the Herbarium of the Mordovia State Nature Reserve, Pushta (HMNR) (Thiers 2015).

The following information is provided for each taxon:

General distribution. A description of the global distribution following the Russian Red Data Book (Bardunov \& Novikov 2008), Terschuren (1999), Wróblewska \& Brzosko (2006), Suško (2008), Vakhrameeva et al. (2014), taking into account the data of Euro + Med PlantBase (2006+).

Distribution before 2003. A number of grid cells consistent with the Mordovian Red Data Book (Silaeva 2003). Information sources for each grid cell are presented in Appendix 1.

Distribution after 2003. A number of grid cells which were established after publication the Mordovian Red Data Book (Silaeva 2003), or older locations which were not considered in this work. Information sources for each grid cell are presented in Appendix 2.

Rarity category in RBRM. Consistent with the Mordovian Red Data Book (Silaeva 2003). If the rarity category was changed, appropriate comments are provided.
The rarity categories used in the Mordovian Red Data Book are described below.

0 - Probably extinct. Populations of these plants have probably disappeared from Mordovia. These plants have not been recorded in the wild during the past 50 years, either in points where the species were known to be formerly present or at any other potential locations. Nevertheless, the possibility that some individuals or populations have been overlooked due to dormancy cannot be completely excluded. Under favorable conditions, plants develop vegetative and/or generative organs and become detectable.

1 - Endangered. Species whose populations have reached critically small sizes and/or their habitats have changed in such a way that their survival is unlikely if the threat factors persist.

2 - Vulnerable. Species characterized by steadily declining populations in the region, which can quickly fall into the endangered category if impacts persist.

3 - Rare. Species of high vulnerability because of their small population size in the region. They are distributed over a limited area or a large scale but at a very low density.

4 - Indeterminate. Species whose populations could be classified into one of the previous categories, but information about their present state is insufficient to accurately determine their status. 
Threatened status in the Republic of Mordovia. This paragraph contains a designation of the threatened status for each plant taxon, considered with IUCN categories. Threat status assessment was based on field observations, newly discovered localities and data from herbarium collections.

\section{Results and Discussion}

In the Table 3, each plant taxon is accompanied by the following data: area of occupancy (AOO); extent of occurrence (EOO); number of populations of plant taxon in Mordovia to number of grid cells where it was found; and the threat assessment of the taxon consistent with the Global Red List and European Red List (Bilz et al. 2011).

\section{Fam. Najadaceae Juss.}

(1) Najas tenuissima (A. Braun ex Magnus) Magnus (Caulinia tenuissima (A. Br. ex Magnus) Tzvelev)

General distribution: Southern Finland, Latvia, Northern Kazakhstan, Russia (several locations in the Leningrad Region, Novgorod Region, Ryazan Region, in the south of Primorsky Krai).

Distribution after 2003: 1 grid cell (Figure 2).
Description: Najas tenuissima was first recorded in Mordovia in 2014. There are two populations of this plant in old small ponds near each other. Individuals of $N$. tenuissima have been observed at a depth of $40-60 \mathrm{~cm}$ on the sandy ground near the embankments. Plant thickets were found on the eastern shallows of ponds among sparse thickets of Potamogeton natans L., Elodea canadensis

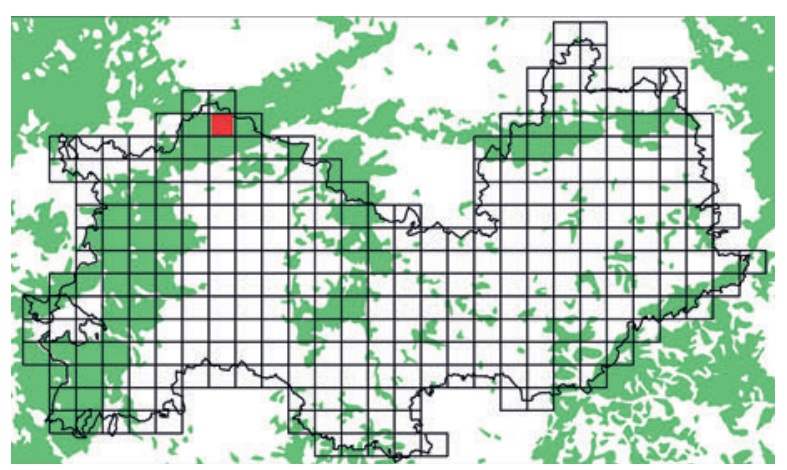

Figure 2: Distribution of Najas tenuissima (A. Braun ex Magnus) Magnus in Mordovia. Indication of locations: gray (red) squares chorological data established after publication of the Mordovian Red Data Book (Silaeva 2003).

Slika 2: Razširjenost vrste Najas tenuissima (A. Braun ex Magnus) Magnus v Mordoviji. Oznaka lokalitet: sivi (rdeči) kvadrati - horološki podatki pridobljeni po objavi rdečega seznama Mordovije (Silaeva 2003).

Table 3: The characteristics of the plant species included in the Red Data Book of the Russian Federation, which occur in the Republic of Mordovia.

Table 3: Značilnosti rastlinskih vrst, vključenih v rdeči seznam Ruske federacije, ki jih najdemo na ozemlju republike Mordovije.

\begin{tabular}{|c|c|c|c|c|c|c|}
\hline \multirow{3}{*}{ Species } & \multicolumn{6}{|c|}{ Result of assessment of plant species } \\
\hline & \multirow[t]{2}{*}{$\begin{array}{l}\text { Global } \\
\text { Red List }\end{array}$} & \multicolumn{2}{|c|}{$\begin{array}{l}\text { European Red List of Vascular Plants } \\
\text { (Bilz et al. 2011) }\end{array}$} & \multirow{2}{*}{$\begin{array}{l}\text { Number of } \\
\text { populations / } \\
\text { grid cells in } \\
\text { Mordovia }\end{array}$} & \multirow[t]{2}{*}{$\begin{array}{l}\text { Total } \mathrm{AOO} \\
\text { (sq. km) }\end{array}$} & \multirow[t]{2}{*}{$\begin{array}{l}\text { Total EOO } \\
(\text { sq. km) }\end{array}$} \\
\hline & & $\begin{array}{l}\text { Geographical } \\
\text { Europe }\end{array}$ & $\begin{array}{l}\text { European Union } \\
27 \text { level (2011) }\end{array}$ & & & \\
\hline $\begin{array}{l}\text { Najas tenuissima (A. Braun ex } \\
\text { Magnus) Magnus }\end{array}$ & - & DD & $\mathrm{EN}$ & $1 / 1$ & 0.1 & one location \\
\hline Koeleria sclerophylla P.A. Smirn. & - & - & - & $1 / 1$ & 0.1 & one location \\
\hline $\begin{array}{l}\text { Stipa dasyphylla (Lindem.) } \\
\text { Czern. ex Trautv. }\end{array}$ & - & - & - & $3 / 3$ & 9.8 & 746.1 \\
\hline Stipa pennata L. & - & - & - & $94 / 69$ & 368 & 16355.6 \\
\hline Stipa pulcherrima K. Koch & - & - & - & $3 / 3$ & 9.3 & 417.6 \\
\hline Stipa zalesskii Wilensky & - & DD & $\mathrm{VU}$ & $5 / 4$ & 14.7 & 92.8 \\
\hline Fritillaria ruthenica Wikst. & - & - & - & $2 / 3$ & 8.5 & 13.7 \\
\hline Iris aphylla L. & - & $\mathrm{DD}$ & $\mathrm{DD}$ & $48 / 34$ & 156 & 14016.6 \\
\hline Cypripedium calceolus $\mathrm{L}$. & $\mathrm{LC}$ & NT & NT & $13 / 13$ & 13.5 & 16565.4 \\
\hline Cephalanthera rubra (L.) Rich. & - & $\mathrm{LC}$ & $\mathrm{LC}$ & $7 / 7$ & 11.4 & 6642.3 \\
\hline Epipogium aphyllum Sw. & - & $\mathrm{LC}$ & $\mathrm{LC}$ & $3 / 3$ & 1.4 & 2388.2 \\
\hline Neottianthe cucullata (L.) Schltr. & - & EN & EN & $3 / 9$ & 15.2 & 5271.2 \\
\hline Orchis militaris L. & - & $\mathrm{LC}$ & $\mathrm{LC}$ & $5 / 5$ & 3.5 & 4526.4 \\
\hline $\begin{array}{l}\text { Neotinea ustulata (L.) R.M. } \\
\text { Bateman, Pridgeon \& M.W. Chase }\end{array}$ & - & - & - & $1 / 1$ & 0.5 & one location \\
\hline Thymus cimicinus Blume ex Ledeb. & - & - & - & $3 / 3$ & 1.6 & 43.4 \\
\hline
\end{tabular}


Michx. and Eleocharis acicularis (L.) Roem. \& Schult. A large number of fruit-bearing plants were noted within revealed populations.

Rarity category in RBRM: 1 - Endangered.

Threatened status in the Republic of Mordovia: Critically Endangered - CR B1ab(i,ii,iii)+2ab(i,ii,iii); C2a(ii). Assessed by E.V. Vargot.

Fam. Poaceae

(2) Koeleria sclerophylla P.A. Smirn. (K. macrantha (Ledeb.) Schult.)

General distribution: North-western regions of $\mathrm{Ka}$ zakhstan on the spurs of the General Syrt; in Russia: in trans-Volga region on the Bugulmino-Belebeevskaya Upland, on the Southern Ural and on the east of the Volga Upland (Bardunov \& Novikov 2008). It is an endemic to the Middle Volga region (Maevskiy 2014).

Distribution after 2003: 1 grid cell (Figure 3).

Description: The long-standing confusion about the presence of this plant taxon in the Republic of Mordovia was resolved by reassessment of the old herbarium specimens (the beginning of the 1980s) in MW. For a long time, this herbarium specimen was kept in MW as Koeleria cristata s.l. But recently it has been established that this specimen belongs to K. sclerophylla (Maevskiy 2014). The population of $K$. sclerophylla is located in neighborhoods of the Sabur-Machkasy village at the outputs of limestone rocks on the north-western spurs of the Volga Upland. The current status of the K. sclerophylla population (AOO, EOO, number of mature individuals, size of population) is unknown due to this species being found in the region only recently.

Rarity category in RBRM: 4 - Indeterminate.

Threatened status in the Republic of Mordovia: Data Deficient-DD. Assessed by T.B. Silaeva, A.A. Khapugin.

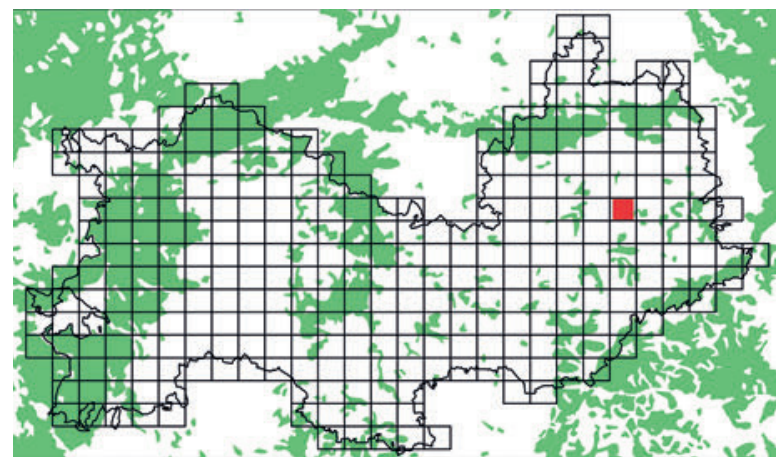

Figure 3: Distribution of Koeleria sclerophylla P.A. Smirn. in Mordovia. Indication of locations: gray (red) squares - chorological data established after publication of the Mordovian Red Data Book (Silaeva 2003).

Slika 3: Razširjenost vrste Koeleria sclerophylla P.A. Smirn. v Mordoviji. Oznaka lokalitet: sivi (rdeči) kvadrati - horološki podatki pridobljeni po objavi rdečega seznama Mordovije (Silaeva 2003).

\section{Fam. Poaceae}

(3) Stipa dasyphylla (Lindem.) Czern. ex Trautv.

General distribution: Austria, Bulgaria, Czech Republic, Germany, Hungary, Moldova, Romania, Russian Federation, Slovakia, Ukraine; range of plant in European Russia occupies a large area in the forest-steppe and steppe zones, on Ural region and Ciscaucasia.

Distribution before 2003: 1 grid cell. These first data about Stipa dasyphylla in the Republic of Mordovia were published by Alekhin \& Averkiev (1927) (Figure 4). However, this record had not been re-found before publication of the Red Data Book of the Republic of Mordovia (Silaeva 2003). Hence, this species was listed as category 0 (Probably extinct).

Distribution after 2003: In 2004 year, the persistence of Stipa dasyphylla at Lobaski was confirmed (Silaeva et al. 2004). In addition, two new locations (i.e. 2 grid cells) were found (Figure 4).

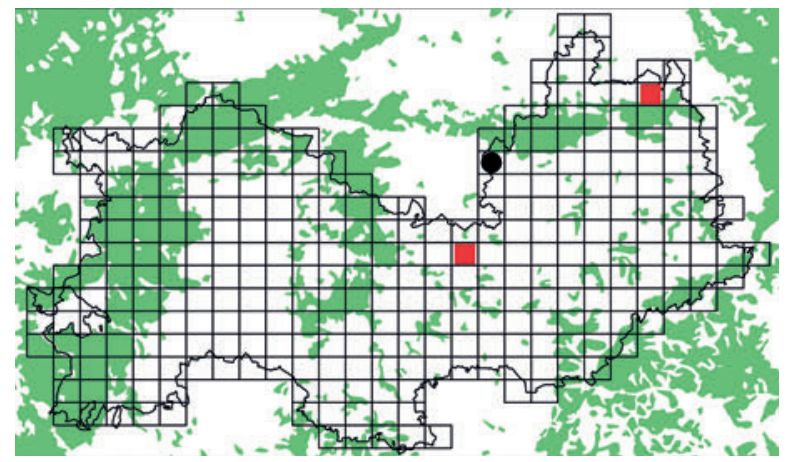

Figure 4: Distribution of Stipa dasyphylla (Lindem.) Czern. ex Trautv. in Mordovia. Indication of locations: gray (red) squares - chorological data established after publication of the Mordovian Red Data Book (Silaeva 2003); black circles - chorological data consistent to the Mordovian Red Data Book (Silaeva 2003)

Slika 4: Razširjenost vrste Stipa dasyphylla (Lindem.) Czern. ex Trautv. v Mordoviji. Oznaka lokalitet: sivi (rdeči) kvadrati - horološki podatki pridobljeni po objavi rdečega seznama Mordovije (Silaeva 2003); črni krog - horološki podatki v skladu z rdečim seznamom Mordovije (Silaeva 2003).

Description: Total AOO in the Republic of Mordovia is 9.8 square kilometers. Three known populations of this species are significantly separated from each other. The largest population (about 200 square meters) is located nearby Konopat. This location is a part of the steppes extending from the Nizhny Novgorod region. Thus, due to the rescue effect (Brown \& Kodric-Brown 1977, Hanski \& Gyllenberg 1993), the IUCN category for Stipa dasyphylla should be downlisted from Critically Endangered (CR) to Endangered (EN). The rarity category of $S$. dasyphylla should be changed from 0 (Probably extinct) to 1 (Endangered) due to the new populations (Olevka and Konopat) and re-location of the population in Lobaski. 
At present, the extinction risk to populations persists, due to the decrease of grazing pressure and increase in the mesophilisation process on the slopes where $S$. dasyphylla occurs.

Rarity category in RBRM: 1 - Endangered.

Threatened status in the Republic of Mordovia: Endangered - EN B2ab(iii). Assessed by T.B. Silaeva, A.A. Khapugin.

\section{Fam. Poaceae}

(4) Stipa pennata L.

General distribution: South Scandinavia (Sweden), Western, Southern and Eastern Europe, Caucasus, Kazakhstan, Turkey; in Russia: Stipa pennata occurs in forest-steppe and steppe areas from the south-eastern part of the Bryansk region to Transbaikalia; on the northern limit of its range, the species reaches Oka River in the Moscow region, Tatarstan, southern part of Udmurtia, south-east part of Perm Krai, estuary of Tom River in the Tomsk region and estuary of the Angara River in the Krasnoyarsk region; on the southern limit of its range, this species reaches to the border with Ukraine and Kazakhstan.

Distribution before 2003: This is the most common Stipa species in Mordovia. Stipa pennata is known from the steppe and meadow-steppe areas, sometimes this plant is observed on abandoned fields, edges of light forests and disturbed habitats. When the regional Red Data Book was published, most localities for $S$. pennata were from the eastern and central parts of Mordovia, except for three records from the west. Total number of grid cells was 46 (Figure 5).

Distribution after 2003: 23 grid cells (Figure 5).

Description: Total AOO and EOO in Mordovia are 368 and 16355.6 square kilometers, respectively. The largest populations of Stipa pennata are located in Simkino, Lobaski, Engalychevo and Gumny. The extent of occurrence is not fragmented. Many Mordovian populations of $S$. pennata are able to the genetic exchange with each other. Decrease of grazing pressure in the last 10 years has contributed to the recovery of many populations in the region (for example, in Simkino). However, the threats to $S$. pennata populations have increased due to mesophilisation of steppe sites. Mesophilisation is reflected in the occupation of steppe areas by rhizomatous perennial grasses (especially by Calamagrostis epigejos (L.) Roth), as a result of the decrease of both grazing pressure and lack of spring burns (Kiryukhin 2011). The rescue effect (Brown \& Kodric-Brown 1977, Hanski \& Gyllenberg 1993 ) is very common for $S$. pennata. Continuous genetic exchange between Mordovian populations and those in adjacent Penza region, Ulyanovsk region, Nizhniy Novgorod region is observed. The IUCN category for
S. pennata is downlisted from VU (Vulnerable) to NT (Near Threatened).

Rarity category in RBRM: 3 - Rare.

Threatened status in the Republic of Mordovia: Near Threatened - NT E. Assessed by A.A. Khapugin, T.B. Silaeva.

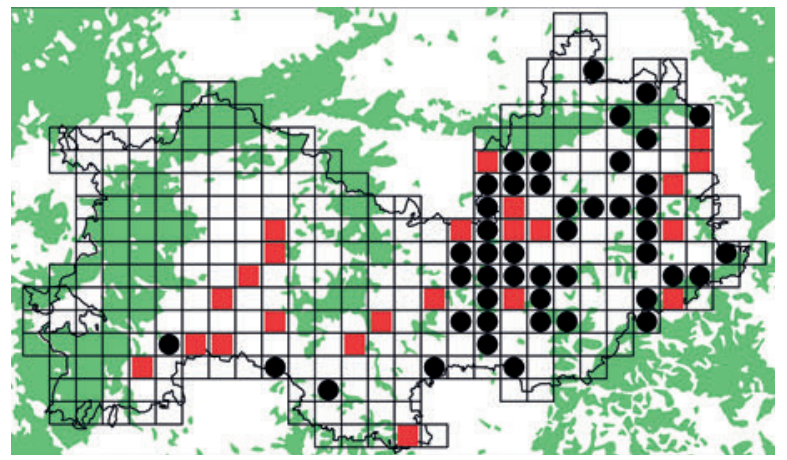

Figure 5: Distribution of Stipa pennata L. in Mordovia. Indication of locations: gray (red) squares - chorological data established after publication of the Mordovian Red Data Book (Silaeva 2003); black circles - chorological data consistent to the Mordovian Red Data Book (Silaeva 2003)

Slika 5: Razširjenost vrste Stipa pennata L. v Mordoviji. Oznaka lokalitet: sivi (rdeči) kvadrati - horološki podatki pridobljeni po objavi rdečega seznama Mordovije (Silaeva 2003); črni krog - horološki podatki v skladu z rdečim seznamom Mordovije (Silaeva 2003).

\section{Fam. Poaceae}

\section{(5) Stipa pulcherrima K. Koch}

General distribution: Western, Southern, Eastern Europe, Caucasus, Northern Africa, Kazakhstan, Turkmenistan, Turkey. In Russia: the species is distributed in foreststeppe and steppe areas of European Russia and Siberia, also in the Caucasus.

Distribution before 2003: 1 grid cell. This first record of Stipa pulcherrima in the Republic of Mordovia was published by Alekhin \& Averkiev (1927) (Figure 6). When Mordovian Red Data Book was published, this species was only known in Mordovia following Alekhin \& Averkiev (1927). Consequently, threat category 0 (Probably extinct) was assigned to $S$. pulcherrima.

Distribution after 2003: 2 grid cells (Figure 6).

Description: Total AOO and EOO in the Republic of Mordovia are 9.3 and 417.6 square kilometers, respectively. The three known populations of Stipa pulcherrima are significantly separated from each other. Populations in Sabur-Machkasy and Simkino cover small areas. However, they contain well-developed plants, annually blooming and seeding. Unfortunately, Alekhin \& Averkiev (1927) report of this endangered species in the steppe natural landmark Endova (location Lobaski) has not been confirmed. When the Mordovian Red Book will be reprinted, the rarity category of $S$. pulcherrima will be changed 
from 0 (Probably extinct) to 1 (Endangered) due to two new records in Sabur-Machkasy and Simkino. Currently, the extinction risk for populations persists due to the decrease of grazing pressure and increase of mesophilisation on the slopes.

Rarity category in RBRM: 1 - Endangered.

Threatened status in the Republic of Mordovia: Critically Endangered - CR B2ab(iii). Assessed by T.B. Silaeva, A.A. Khapugin.
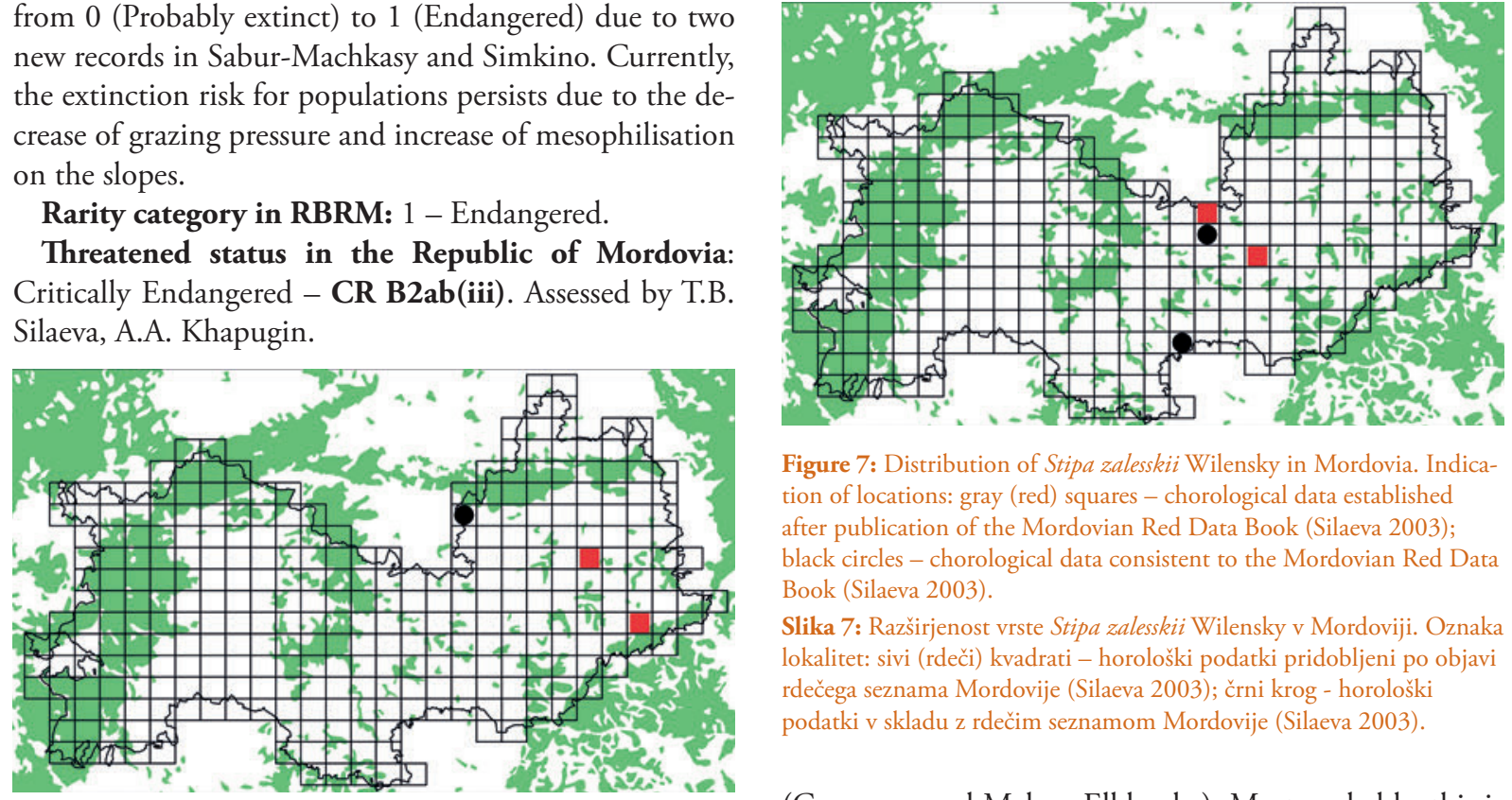

Figure 7: Distribution of Stipa zalesskii Wilensky in Mordovia. Indication of locations: gray (red) squares - chorological data established after publication of the Mordovian Red Data Book (Silaeva 2003); black circles - chorological data consistent to the Mordovian Red Data Book (Silaeva 2003).

Slika 7: Razširjenost vrste Stipa zalesskii Wilensky v Mordoviji. Oznaka lokalitet: sivi (rdeči) kvadrati - horološki podatki pridobljeni po objavi rdečega seznama Mordovije (Silaeva 2003); črni krog - horološki podatki v skladu z rdečim seznamom Mordovije (Silaeva 2003).

Figure 6: Distribution of Stipa pulcherrima K. Koch in Mordovia. Indication of locations: gray (red) squares - chorological data established after publication of the Mordovian Red Data Book (Silaeva 2003); black circles - chorological data consistent to the Mordovian Red Data Book (Silaeva 2003).

Slika 6: Razširjenost vrste Stipa pulcherrima K. Koch v Mordoviji. Oznaka lokalitet: sivi (rdeči) kvadrati - horološki podatki pridobljeni po objavi rdečega seznama Mordovije (Silaeva 2003); črni krog - horološki podatki v skladu z rdečim seznamom Mordovije (Silaeva 2003).

\section{Fam. Poaceae}

\section{(6) Stipa zalesskii Wilensky}

General distribution: In Eastern Europe (Bulgaria, Crimea, Czech Republic, Moldova, Romania, Russian Federation, Slovakia, Ukraine) distributed up to the Czech Republic in the west, Caucasus (Azerbaijan, Armenia, Georgia), Kazakhstan, Turkey; in Russia: this species covers a broad range in the steppe zone and partly in the forest-steppe zone of European Russia, on the Stavropol Upland, in the basin of the upper reaches of the $\mathrm{Ob}$ river and Enisey river, in the lower and middle belts of mountains of the Altai and Western Sayan.

Distribution before 2003: When the Mordovian Red Book (Silaeva 2003) was published, this species was known from only two locations (i.e. 2 grid cells) (Figure 7).

Distribution after 2003: 2 grid cells (Figure 7).

Description: Total AOO and EOO in the Republic of Mordovia are 14.7 and 92.8 square kilometers, respectively. All populations cover small areas. Sometimes (e.g. in the location Palaevka), they are represented by fragmented tufts. The population at Malaya Elkhovka differs from others by the presence of well-developed plants with large tufts. Stipa zalesskii was found in two new locations

(Govorovo and Malaya Elkhovka). Most probably, this is a result of the recovery of oppressed steppe vegetation due to a decrease of high level of grazing pressure. However, the overall extinction risk for populations of the Stipa zalesskii can be increased due to the absolute decrease of grazing pressure and consequent increase of mesophilisation in the steppe plots.

Rarity category in RBRM: 1 - Endangered.

Threatened status in the Republic of Mordovia: Endangered - EN B1ab(iii). Assessed by T.B. Silaeva, A.A. Khapugin.

\section{Fam. Liliaceae}

(7) Fritillaria ruthenica Wikst.

General distribution: Forest-steppe and steppe zones of Belarus, Ukraine, European Russia and North-Western Kazakhstan. In addition, the species is sparsely distributed in Western Siberia (the most eastern locations are located on the Tobol river in the Kurgan region).

Distribution before 2003: 3 grid cells (Figure 3).

Distribution after 2003: After publication of the Mordovian Red Data Book, no new locations of Fritillaria ruthenica were found. The last observation of $F$. ruthenica in the grid cell 54/45-61 was in 2006 (Figure 8).

Description: Total AOO and EOO in Mordovia are 8.5 and 13.7 square kilometers, respectively. The increase of urban areas and the resultant disturbance of habitats of Fritillaria ruthenica are the most significant threats to the populations of this species in Saransk. Similarly, the population in Krivozerye is exposed to other anthropogenic impacts. There, the main influencing factor is overharvesting of wood resources. 


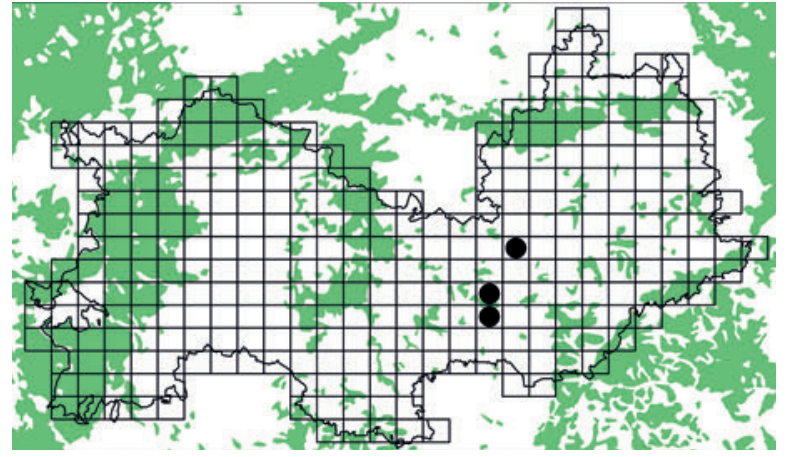

Figure 8: Distribution of Fritillaria ruthenica Wikst. in Mordovia. Indication of locations: black circles - chorological data consistent to the Mordovian Red Data Book (Silaeva 2003).

Slika 8: Razširjenost vrste Fritillaria ruthenica Wikst. v Mordoviji. Oznaka lokalitet: črni krog - horološki podatki v skladu z rdečim seznamom Mordovije (Silaeva 2003).

Rarity category in RBRM: 1 - Endangered.

Threatened status in the Republic of Mordovia: Critically Endangered - CR B1ab(i,ii,iii,v); B2ab(i,ii,iii,v); C2b; D. Assessed by T.B. Silaeva, A.A. Khapugin.

\section{Fam. Iridaceae}

(8) Iris aphylla L.

General distribution: Iris aphylla occurs predominantly in Belarus, Ukraine, Central and South Russia, the Caucasus and Asia Minor; also in Western, Southern and Eastern Europe. In Poland, Belarus, Germany, the Czech Republic, Slovakia, Hungary and Romania populations of this species are at the limit of its geographical range.

Distribution before 2003: When the Mordovian Red Book was published, Iris aphylla was predominantly

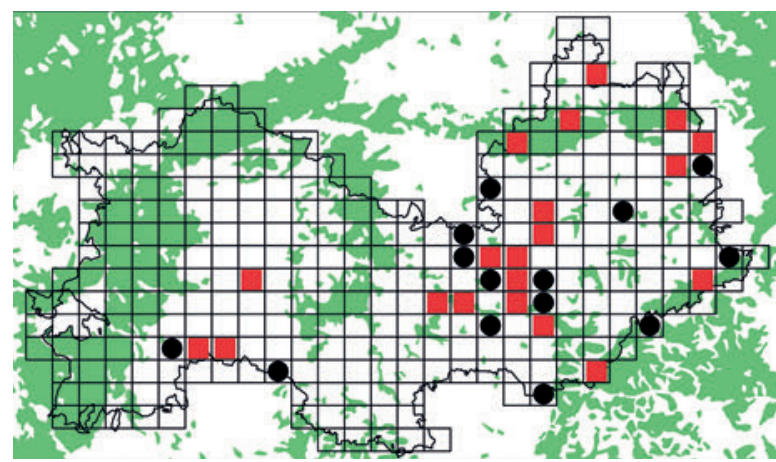

Figure 9: Distribution of Iris aphylla L. in Mordovia. Indication of locations: gray (red) squares - chorological data established after publication of the Mordovian Red Data Book (Silaeva 2003); black circles - chorological data consistent to the Mordovian Red Data Book (Silaeva 2003).

Slika 9: Razširjenost vrste Iris aphylla L. v Mordoviji. Oznaka lokalitet: sivi (rdeči) kvadrati - horološki podatki pridobljeni po objavi rdečega seznama Mordovije (Silaeva 2003); črni krog - horološki podatki v skladu z rdečim seznamom Mordovije (Silaeva 2003). known from the eastern part of Mordovia. Only two locations were known in the west of the region. This species was recorded in 14 grid cells within Mordovia (Figure 9).

Distribution after 2003: 20 grid cells (Figure 9).

Description: Total AOO and EOO in the Republic of Mordovia are 156 and 14016.6 square kilometers, respectively. Iris aphylla occurs mostly in the central and eastern parts of Mordovia. Only three locations were found in the west. Many populations of this species are stable due to the development of powerful rhizomatous thickets. The principal threat to I. aphylla is disturbance of natural habitats due to plowing the land, forest logging and the construction of human settlements.

Rarity category in RBRM: 2 - Vulnerable.

Threatened status in the Republic of Mordovia: Vulnerable - VU C2a(i). Assessed by T.B. Silaeva, A.A. Khapugin.

\section{Fam. Orchidaceae}

(9) Cypripedium calceolus $\mathrm{L}$.

General distribution: Outside Russia, the range includes Europe (northward to the Arctic Circle in Fennoscandia and southward to the Pyrenees, the Alpine Arc and the Carpathians), Northern and Northwestern Kazakhstan, Mongolia, North China, Korea, Japan and North America. In Russia, Cypripedium calceolus is distributed throughout the forest zone of European Russia (except the Far North), in the Urals, in the southern part of Siberia and the Far East, including Sakhalin. Records of C. calceolus in the Northern Caucasus refer to cultivated plants.

Distribution before 2003: 11 grid cells (Figure 10).

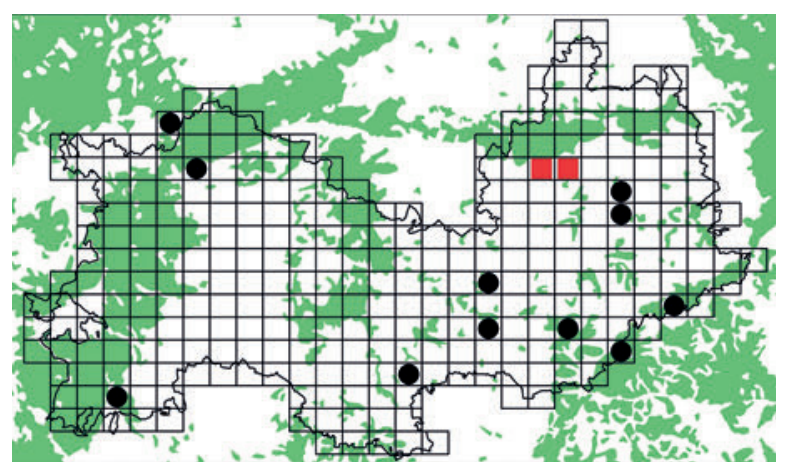

Figure 10: Distribution of Cypripedium calceolus L. in Mordovia. Indication of locations: gray (red) squares - chorological data established after publication of the Mordovian Red Data Book (Silaeva 2003); black circles - chorological data consistent to the Mordovian Red Data Book (Silaeva 2003).

Slika 10: Razširjenost vrste Cypripedium calceolus L. v Mordoviji. Oznaka lokalitet: sivi (rdeči) kvadrati - horološki podatki pridobljeni po objavi rdečega seznama Mordovije (Silaeva 2003); črni krog - horološki podatki v skladu z rdečim seznamom Mordovije (Silaeva 2003). 
Distribution after 2003: 2 grid cells (Figure 10).

Description: Total AOO and EOO in Mordovia are 13.5 and 16565.4 square kilometers, respectively. Despite this large area of EOO, almost all locations are significantly separated from each other. Populations of Cypripedium calceolus in Levzhenskiy, Saransk, Sabur-Machkasy and between Gart and Degilevka have not been re-found for many years. Rosstanye was damaged by fire in 2010 . Throughout the last 12 years, C. calceolus was found in two new grid cells in Mordovia. These are populations in Kamchatka and Tashkino within the extended forest area. The most stable and the largest populations of this species are known in Simkino, Pushta, Lyambir, Kamchatka and Tashkino. Among them, the location Pushta has the most favorable conditions for C. calceolus (Khapugin et al. 2014).

Rarity category in RBRM: 2 - Vulnerable.

Threatened status in the Republic of Mordovia: Critically Endangered - CR C2a(ii). Assessed by T.B. Silaeva, A.A. Khapugin.

\section{Fam. Orchidaceae}

(10) Cephalanthera rubra (L.) Rich.

General distribution: In Europe, Cephalanthera rubra is distributed from the Mediterranean region to southern Scandinavia, but also from the North Africa, the northern part of Asia Minor, Iran and Turkmenistan. In Russia, the range is subdivided into two fragments: the first fragment covers most areas of the Centre of European Russia and parts of the Volga territory and on the Urals; the second fragment is located in the mountains and foothills of the North Caucasus.

Distribution before 2003: 5 grid cells (Figure 11). Distribution after 2003: 2 grid cells (Figure 11).

Description: Total AOO and EOO in Mordovia are 11.4 and 6642.3 square kilometers, respectively. Despite this large area of EOO, Cephalanthera rubra is represented by few locations which are significantly distant from each other. New populations of Cephalanthera rubra were found in two grid cells in Mordovia. These new data are very important to reduce its extinction risk in the region due to fact that all populations of Cephalanthera rubra from the Mordovia State Nature Reserve (location Pushta: grid cells 54/43-13, 54/43-14) were damaged by fire in 2010; and they have not been found since. In addition, populations in Russkie Dubrovki and Gart have not been re-found for a few decades. Within grid cell 54/46-56, a few populations of the C. rubra are treated as a single location, as a geographically distinct area in which a single threatening event can rapidly affect all individuals of the taxon (IUCN 2012a). Individuals of this species are observed in the locations Simkino and Tashkino annually.
Rarity category in RBRM: 1 - Endangered.

Threatened status in the Republic of Mordovia: Critically Endangered - CR C2a(i,ii). Assessed by T.B. Silaeva, A.A. Khapugin.

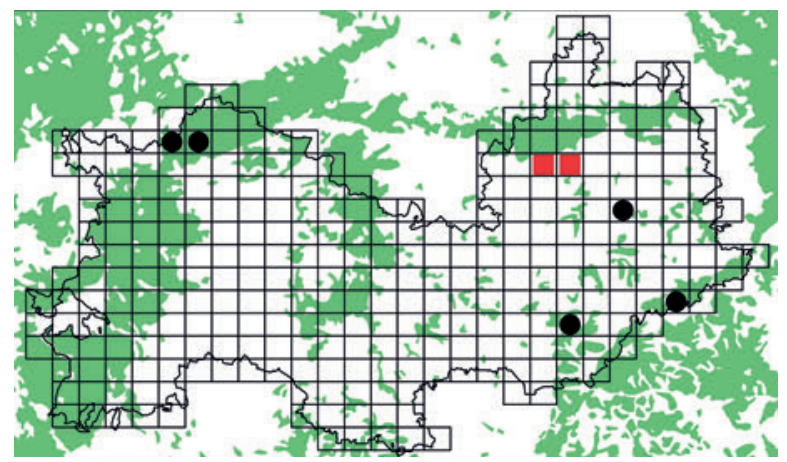

Figure 11: Distribution of Cephalanthera rubra (L.) Rich. in Mordovia. Indication of locations: gray (red) squares - chorological data established after publication of the Mordovian Red Data Book (Silaeva 2003); black circles - chorological data consistent to the Mordovian Red Data Book (Silaeva 2003).

Slika 11: Razširjenost vrste Cephalanthera rubra (L.) Rich. v Mordoviji. Oznaka lokalitet: sivi (rdeči) kvadrati - horološki podatki pridobljeni po objavi rdečega seznama Mordovije (Silaeva 2003); črni krog - horološki podatki v skladu z rdečim seznamom Mordovije (Silaeva 2003).

\section{Fam. Orchidaceae}

\section{(11) Epipogium aphyllum Sw.}

General distribution: The range of E. aphyllum includes almost the whole Europe (up to $66^{\circ} \mathrm{N}$ Lat.), the mountains of Asia Minor, Ciscaucasia, Mongolia, China, the Himalayas, Korea and Japan. In Russia, range is subdivided into three fragments: the largest fragment reaches from the Baltic Sea to 120 degrees of east longitude; the second fragment of range covers the Khabarovsk Krai and Primorsky Krai, Amur region, Sakhalin region and Kamchatka region; the third fragment of range includes the southern and south-western parts of Russia.

Distribution before 2003: 3 grid cells (Figure 12).

Distribution after 2003: New locations of Epipogium aphyllum have not been found following publication of the Mordovian Red Book (Silaeva 2003) (Figure 12).

Description: Epipogium aphyllum is a very rare mycotrophic orchid. This species is known from three locations which are considerably distant from each other. AOO is 1.4 square kilometers, and EOO is a very fragmented. Individuals of this species may manifest only in very rainy years. In Staroe Badikovo and Simkino, records of $E$. aphyllum have not been re-found for 35 years. Moreover, E. aphyllum in Zubova Polyana has not been re-found for over 130 years. Probably, the habitat of this species was destroyed due to expansion of the Zubova Polyana settlement. 
Rarity category in RBRM: 1 - Endangered.

Threatened status in the Republic of Mordovia: Critically Endangered - CR B2ab(iii)c(iv); C2b(i,ii); D. Assessed by T.B. Silaeva, A.A. Khapugin.

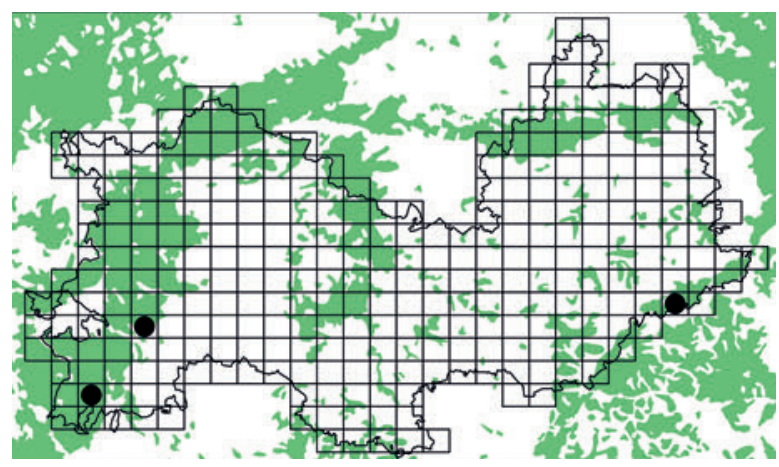

Figure 12: Distribution of Epipogium aphyllum Sw. in Mordovia. Indication of locations: black circles - chorological data consistent to the Mordovian Red Data Book (Silaeva 2003).

Slika 12: Razširjenost vrste Epipogium aphyllum Sw. v Mordoviji. Oznaka lokalitet: črni krog - horološki podatki v skladu z rdečim seznamom Mordovije (Silaeva 2003).

\section{Fam. Orchidaceae}

(12) Neottianthe cucullata (L.) Schltr.

General distribution: Middle and Eastern Europe (including Belarus, Ukraine, Baltic countries), Kazakhstan, Mongolia, North China, Japan and Korea. In Russia, this species is sporadically distributed; the northern boundary of the range is at $56-58^{\circ} \mathrm{N}$ Lat.

Distribution before 2003: 9 grid cells (Figure 13).

Distribution after 2003: 1 grid cell (Figure 13).

Description: Total AOO and EOO in Mordovia are 15.2 and 5271.2 square kilometers, respectively. Neottianthe cucullata is a small orchid, inhabiting the moss layer in pine forests. We consider all records of $N$. cucullata from the Mordovia State Nature Reserve (4 grid cells) as a single location, as well as all records from the National Park "Smolny" (5 grid cells) as a single location. This agrees with the definition of a term "location", as a geographically or ecologically distinct area in which a single threatening event can rapidly affect all individuals of the taxon present, according to Version 3.1 of "IUCN Red List Categories and Criteria" (2012a). In 2010, a few populations were damaged by fire. As a result, they have not been re-found here. On the other hand, new $N$. cucullata populations were found in Simkino (in the southeast of Mordovia) in 2004. Each includes only a small number of individuals. In contrast, relatively large areas (up to 200 square meters) support populations in the Mordovia State Nature Reserve and, especially, in the National Park "Smolny".
Rarity category in RBRM: 2 - Vulnerable.

Threatened status in the Republic of Mordovia: Endangered - EN B2ab(iii,iv)c(iv). Assessed by A.A. Khapugin, T.B. Silaeva.

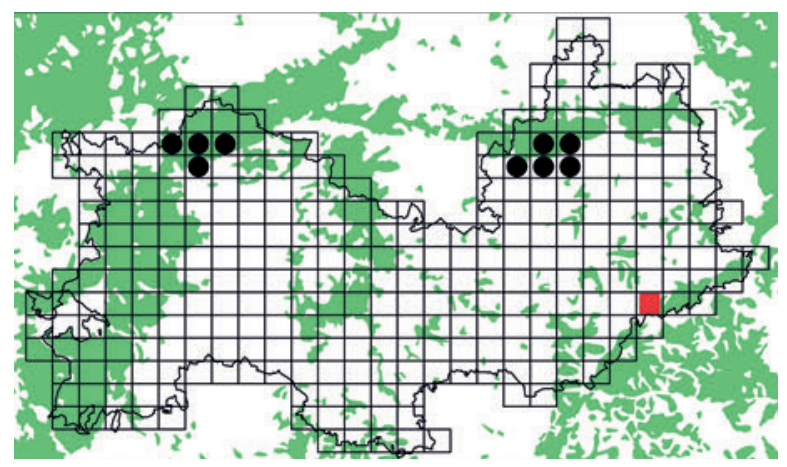

Figure 13: Distribution of Neottianthe cucullata (L.) Schltr. in Mordovia. Indication of locations: gray (red) squares - chorological data established after publication of the Mordovian Red Data Book (Silaeva 2003); black circles - chorological data consistent to the Mordovian Red Data Book (Silaeva 2003).

Slika 13: Razširjenost vrste Neottianthe cucullata (L.) Schltr. v Mordoviji. Oznaka lokalitet: sivi (rdeči) kvadrati - horološki podatki pridobljeni po objavi rdečega seznama Mordovije (Silaeva 2003); črni krog - horološki podatki v skladu z rdečim seznamom Mordovije (Silaeva 2003).

\section{Fam. Orchidaceae}

(13) Orchis militaris L.

General distribution: Europe, Asia Minor, Iran, Mongolia, Northwest China, and also isolated localities in northern Kazakhstan. In Russia, the range extends across the whole country from the western border of Russia to Transbaikalia. "Island" locations are known in the Arkhangelsk region, Vologda region, on the Southern Urals and

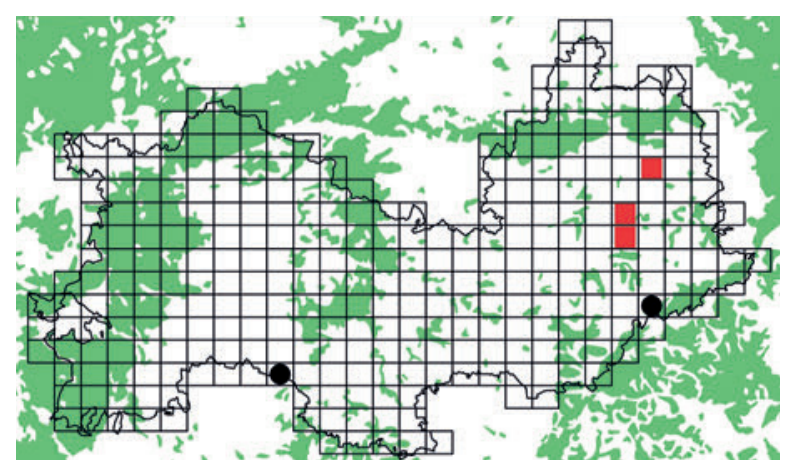

Figure 14: Distribution of Orchis militaris L. in Mordovia. Indication of locations: gray (red) squares - chorological data established after publication of the Mordovian Red Data Book (Silaeva 2003); black circles - chorological data consistent to the Mordovian Red Data Book (Silaeva 2003).

Slika 14: Razširjenost vrste Orchis militaris L. v Mordoviji. Oznaka lokalitet: sivi (rdeči) kvadrati - horološki podatki pridobljeni po objavi rdečega seznama Mordovije (Silaeva 2003); črni krog - horološki podatki v skladu z rdečim seznamom Mordovije (Silaeva 2003). 
southern Yakutia. A smaller area of occurrence includes the southern regions of Russia and the Greater Caucasus.

Distribution before 2003: The first record of Orchis militaris in Mordovia was in 1980 (Silaeva 2003). Herbarium specimens from 2 locations (i.e. 2 grid cells) were collected later (Figure 14).

Distribution after 2003: 3 grid cells (Figure 14).

Description: Orchis militaris inhabits moist flood meadows in Mordovia. Total AOO and EOO in Mordovia are 3.5 and 4526.4 square kilometers, respectively. After publication of the Mordovian Red Book, three new locations were found in Mordovia. However, populations in Kamenka, Chepurnovka and Sabur-Machkasy support only a few individuals. Populations of $O$. militaris in Simkino and Komsomolskiy contain individuals of all age classes (juvenile, mature vegetative, generative). They are represented by annually blooming and fructifying individuals. In Komsomolskiy O. militaris is located near the railroad within a large industrial complex; this population of $O$. militaris has the greatest extinction risk among all locations known in the region.

Rarity category in RBRM: 1 - Endangered.

Threatened status in the Republic of Mordovia: Critically Endangered - CR B2ab(iii,v); C2b(i,ii). Assessed by T.B. Silaeva, A.A. Khapugin.

\section{Fam. Orchidaceae}

(14) Neotinea ustulata (L.) R.M. Bateman, Pridgeon \& M.W. Chase (Orchis ustulata L.)

General distribution: Europe, Transcaucasia, Asia Minor; in Russia, Neotinea ustulata is distributed over a large part of European Russia and slightly beyond the Ural mountains (up to $68-69^{\circ}$ E Long.), and also on the Greater Caucasus.

Distribution before 2003: 1 grid cell (Figure 15).

Distribution after 2003: No new records of this species were found in Mordovia after publication of the Mordovian Red Book (Figure 15).

Description: Neotinea ustulata was recorded for the first time 130 years ago in northwestern Mordovia. This location has not been re-found. Nevertheless, the population of this long-lived species should not be classified as Regionally Extinct, consistent with IUCN red list criteria at regional and national levels (IUCN 2012b). The ability to survive without forming any above-ground parts is the main reason of the apparent rarity of $N$. ustulata in the Republic of Mordovia. N. ustulata requires annual targeted study to clarify its current status.

Rarity category in RBRM: 0 - Probably extinct.

Threatened status in the Republic of Mordovia: Critically Endangered - CR B1ab(ii,iii)c(iv); B2ab(ii,iii)c(iv); C2b(i,ii); D; E. Assessed by T.B. Silaeva, A.A. Khapugin.

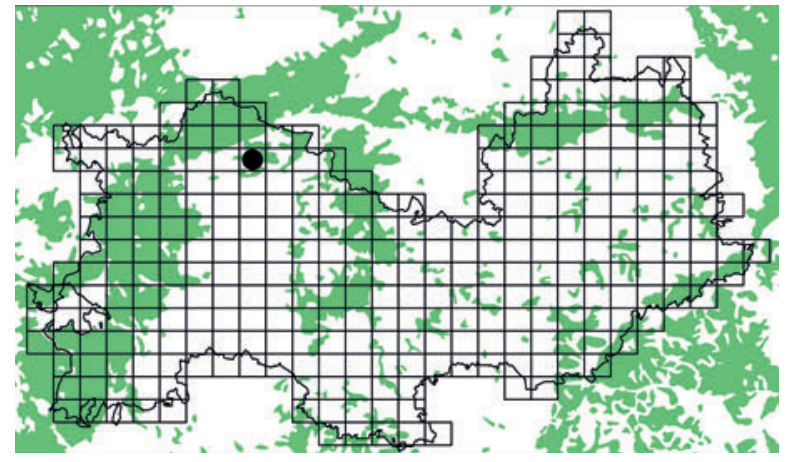

Figure 15: Distribution of Neotinea ustulata (L.) R.M. Bateman, Pridgeon \& M.W. Chase in Mordovia. Indication of locations: black circles - chorological data consistent to the Mordovian Red Data Book (Silaeva 2003).

Slika 15: Raž̌irjenost vrste Neotinea ustulata (L.) R.M. Bateman, Pridgeon \& M.W. Chase v Mordoviji. Oznaka lokalitet: črni krog - horološki podatki v skladu z rdečim seznamom Mordovije (Silaeva 2003).

\section{Fam. Lamiaceae}

(15) Thymus cimicinus Blume ex Ledeb.

General distribution: Forest-steppe and steppe zones of south-eastern European Russia, the South Urals and the Volga Upland.

Distribution before 2003: 3 grid cells (Figure 16).

Distribution after 2003: No new records of Thymus cimicinus were found in Mordovia after publication of the Mordovian Red Book (Figure 16).

Description: Thymus cimicinus is a dwarf subshrub of calciphilous steppe. This is known from three locations in Mordovia. Total AOO and EOO in the region are 1.6 and 43.4 square kilometers, respectively. The main reason for rarity of $T$. cimicinus is the lack of suitable habitat (the outputs of limestone rocks). Currently, colonization of limestone outcrops by rhizomatous perennial grasses due to the lack or low grazing pressure is the main threat.

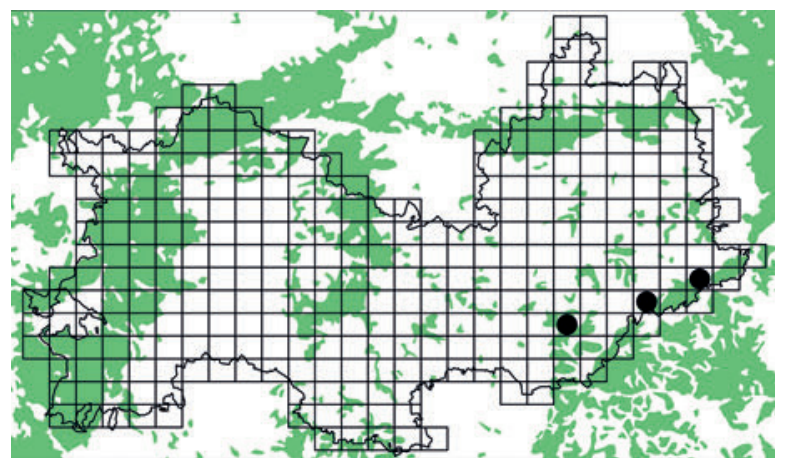

Figure 16: Distribution of Thymus cimicinus Blume ex Ledeb. in Mordovia. Indication of locations: black circles - chorological data consistent to the Mordovian Red Data Book (Silaeva 2003). Slika 16: Razširjenost vrste Thymus cimicinus Blume ex Ledeb. v Mordoviji. Oznaka lokalitet: črni krog - horološki podatki v skladu z rdečim seznamom Mordovije (Silaeva 2003). 
In addition, the population of T. cimicinus in Gart has not yet been re-found. Besides the locations listed above (Simkino; Engalychevo; between Gart and Degilevka), there are two further sites (Kamenka, Selishchi) where environmental conditions are favorable for T. cimicinus in Mordovia.

Rarity category in RBRM: 1 - Endangered.

Threatened status in the Republic of Mordovia: Critically Endangered - CR B1ab(iii); B2ab(iii). Assessed by T.B. Silaeva, A.A. Khapugin.

\section{Conclusions}

During the 12 years since publication of the Red Book of Mordovia, we collected abundant herbarium material and assembled numerous unpublished and new chorological data for 15 plant species included in the Russian Red Book. The assessment of their threat status followed the new IUCN criteria and guidelines (IUCN 2012a, 2012b, 2014). Nine taxa were assessed as Critically Endangered (Najas tenuissima, Stipa pulcherrima, Fritillaria ruthenica, Cypripedium calceolus, Cephalanthera rubra, Epipogium aphyllum, Orchis militaris, Neotinea ustulata, Thymus cimicinus), three as Endangered (Stipa dasyphylla, Stipa zalesskii, Neottianthe cucullata), one as Vulnerable (Iris aphylla), one as Near Threatened (Stipa pennata) and one as Data Deficient (Koeleria sclerophylla). The available herbarium collections and comprehensive literature data were examined in order to complete distribution maps for these 15 plant species in Mordovia.

Following the publication of the Mordovian Red Book, new records of Fritillaria ruthenica, Epipogium aphyllum, Neotinea ustulata and Thymus cimicinus were not found in Mordovia. The first three species can persist a dormant state over an extended period of time. Hence, search and monitoring for these species are difficult. Targeted studies are needed in the known locations in the most appropriate season. New populations of T. cimicinus in Mordovia may be revealed on areas with limestone rock outcrops.

All new locations of all Stipa spp. are directly associated with decreased grazing pressure in Mordovia. However, the absolute lack of the grazing and of spring burns may lead to declines of Stipa populations, due to mesophilisation of steppe sites. This process manifests in penetration of other rhizomatous perennial grasses in the steppe areas and subsequent overgrowth of these perennials in these places.

We consider that all plant species listed above should be included in the next edition of the Mordovian Red Data Book. Fritillaria ruthenica, Epipogium aphyllum, Neotinea ustulata and Thymus cimicinus require additional studies to confirm earlier observations.

\section{Acknowledgements}

Authors thank to O.G. Grishutkin for advice and support during field studies; and to E.V. Pismarkina and A.M. Ageeva for consultations regarding of distribution of several plant species in the Republic of Mordovia. We are very grateful to two anonymous reviewers for careful attention to the manuscript and valuable comments. This work was supported by the Ministry of Education and Science of Russia (project № 6.783.2014K).

\section{References}

Abramova, L.A., Volkova, P.A., Borisova, P.B. \& Mitireva, E.A. 2011: Preliminary results of grid mapping of flora of Udomlya district of Tver region. Vestnik Tverskogo gosudarstvennogo universiteta. Seriya biologia i ecologia 24: 127-143 [In Russian].

Ageeva, A.M., Khapugin, A.A., Silaeva, T.B., Vargot, E.V., Pismarkina, E.V. \& Chugunov, G.G. 2012: Rare vascular plants in the Moksha river basin in the Republic of Mordovia. Proceedings of Samara Scientific Center RAS 14(1): 1676-1680 [In Russian].

Alekhin, V.V. \& Averkiev, D.S. 1927: Vegetation of steppe Transalatyrye. In: Alekhin V.V. (ed.). The preliminary report on the studies of the Nizhny Novgorod geobotanical expedition in 1926 year. Nizhny Novgorod, pp. 15-23 [In Russian].

Bakka, S.V. \& Kiseleva, N.Yu. 2008: Protected Areas of Nizhny Novgorod region. Annotated list. Nizhny Novgorod, 560 pp. [In Russian].

Bardunov, L.V. \& Novikov, V.S. (Eds.). 2008: Red Book of Russian Federation (plants and fungi). KMK Scientific Press Ltd., Moscow, 855 pp. [In Russian].

Bilz, M., Kell, S.P., Maxted, N. \& Lansdown, R.V. 2011: European Red List of Vascular Plants. Publications Office of the European Union, Luxembourg, 144 pp.

Blinova, I.V. \& Uotila, P. 2011: Chamorchis alpina and Epipactis helleborine in the Murmansk Region, Russia, and assessments of the orchids in the Region using the IUCN Red List Categories. Memoranda Soc. Fauna Flora Fennica 87: 21-28.

Brown, J.H. \& Kodric-Brown, A. 1977: Turnover rates in insular biogeography: effect of immigration on extinction. Ecology 58 : 445-449.

Chernyagina, O.A. (ed.). 2007: Red Data Book of Kamchatka, vol. 2: Plants, mushrooms and thermophilic microorganisms. Kamchatsky Pechatny Dvor Publishing House, Petropavlovsk-Kamchatsky, 341 pp. [In Russian].

Chkalov, A.V. \& Pakina, D.V. 2014: Genus Alchemilla L. in the flora of the Mordovia State Reserve. In: Artaev, O.N., Vargot, E.V., Ruchin, A.B. \& Khapugin A.A. (eds.): Ecological-geographical studies of natural objects in Russia and adjacent countries. Publisher of the Mordovia State University, Saransk, pp. 103-106 [In Russian].

Chugunov, G.G., Khapugin, A.A. \& Vargot, E.V. 2011 a: About stocktaking of plants of Red Data Book of the Republic of Mordovia 
in the Mordovia State Nature Reserve. Proceedings of the Mordovia State Nature Reserve 9: 232-240 [In Russian].

Chugunov, G.G., Khapugin, A.A., Vargot, E.V., Silaeva, T.B., Kiryukhin, I.V. \& Fedyashkina, A.N. 2011b: Synopsis of vascular plants of the flora of national park "Smolny" included in the Red Data Book of the Republic of Mordovia. Proceedings of the Mordovia State Nature Reserve 9: 241-255 [In Russian].

Efimov, P.G. 2012: Orchids of north-west European part of Russia, second edition. KMK Scientific Press Ltd., Moscow, 220 pp. [In Russian].

Eliáš jun., P., Dítě, D., Kliment, J., Hrivnák, R. \& Feráková, V. 2015: Red list of ferns and flowering plants of Slovakia, 5th edition (October 2014). Biologia 70(2): 218-228.

Euro+Med. 2006+: Euro+Med PlantBase - the information resource for Euro-Mediterranean plant diversity. Published on the Internet http://ww2.bgbm.org/EuroPlusMed/ [accessed 24. 03. 2016].

Grishutkin, O.G. 2013: Possibility of using of GIS in botanical researches. Mordovia University Bulletin 3-4: 16-20 [In Russian].

Hanski, I. \& Gyllenberg, M. 1993: Two general metapopulation models and the coresatellite species hypothesis. The American Naturalist 142: 17-41.

IUCN Standards and Petitions Subcommittee. 2014: Guidelines for Using the IUCN Red List Categories and Criteria. Version 11. Prepared by the Standards and Petitions Subcommittee. Downloadable from http://www.iucnredlist.org/documents/RedListGuidelines.pdf.

IUCN. 2012a: IUCN Red List Categories and Criteria: Version 3.1, second ed. Gland, Switzerland and Cambridge, UK, 32 pp.

IUCN. 2012b: Guidelines for Application of IUCN Red List Criteria at Regional and National Levels: Version 4.0. Gland, Switzerland and Cambridge, UK, 41 pp.

Khapugin, A.A. 2012: About Finding of Rosa glauca Pourr. (Rosaceae) in the Republic of Mordovia. Russian Journal of Biological Invasions 3(1): 56-57. doi: 10.1134/S2075111712010043

Khapugin, A.A. 2013: Vascular plants of the Romodanovo district of the Republic of Mordovia. Saransk; Pushta, 110 pp. [In Russian]

Khapugin, A.A. \& Buzunova, I.O. 2013: The synopsis of section Caninae DC. of genus Rosa L. (Rosaceae) in the flora of the Moksha river basin. Novosti sistematiki vysšich rastenij 44: 135-145 [In Russian].

Khapugin, A.A. \& Silaeva, T.B. 2013: The Cover of Steppe Vascular Plants by the Protected Area Network of the Republic of Mordovia (Russia). In: Morales Prieto, M.B. \& Traba Diaz, J. (eds.): Steppe Ecosystems: Biological Diversity, Management and Restoration. Nova Science Publishers, Inc., New York, pp. 211-220.

Khapugin, A.A., Semchuk, A.A., Silaeva, T.B. \& Chugunov, G.G. 2014: A comparative characteristics of Cypripedium calceolus L. (Orchidaceae, Monocotyledones) coenopopulations in the Republic of Mordovia. Povolzhskiy Journal of Ecology 3: 403-410 [In Russian].

Kiryukhin, I.V. 2011: About some coenotic features of the Stipa pennata L. (Gramineae) in Mordovia. Proceedings of Samara Scientific Center RAS 13(5): 68-70 [In Russian].

Konstantinova, N.A., Koryakin, A.S. \& Makarova, O.A. (eds.). 2003: The Red Data Book of the Murmansk Region. Administration of Nature Resources and Environment of Protection on Murmansk Region, Murmansk, 393 pp. [In Russian].

Konstantinova, N.A., Koryakin, A.S., Makarova, O.A. \& Bianki, V.V. (eds.). 2014: The Red Data Book of the Murmansk Region, second edition. Asia-print, Kemerovo, 582 pp. [In Russian].

Kuznetsov, V.A. \& Silaeva, T.B. (eds.). 2008: Protected areas and objects of the Republic of Mordovia. Materials to the single package of cadastral data. Saransk, 388 pp. [In Russian].

Maevskiy, P.F. 2014: Flora of Center of European part of Russia. KMK Scientific Press Ltd., Moscow, 635 pp. [In Russian].

Malyshev, L.I. \& Peshkova, G.A. (Eds.). 1979: Flora of the Central Siberia. Nauka, Novosibirsk, 1045 pp. [In Russian].

Mather, A. 2001: The transition from deforestation to reforestation in Europe. In: Angelsen, A. \& Kaimowitz, D. (eds.): Agricultural technologies and tropical deforestation. CABI, New York, pp. 35-54.

Mayorov, S.R. 1993: Flora of the Republic of Mordovia. PhD thesis. Moscow State University, Moscow, 15 pp. [In Russian].

Moreno Saiz, J.C., Domínguez Lozano, F., Marrero Gómez, M.V. \& Bañares Baudet, Á. 2015: Application of the Red List Index for conservation assessment of Spanish vascular plants. Conservation Biology 29(3): 910-919.

Novikov, V.S., Oktyabreva, N.B., Silaeva, T.B. \& Tikhomirov, V.N 1989: New species for the flora of Mordovia. Biological Sciences 4: 55-61 [In Russian].

Pismarkina, E.V., Silaeva, T.B. \& Vorsobina, L.I. 2001: Natural landmark Endova as an extant plot of steppe vegetation. In: Teltsov, L.P., Trofimov, V.A., Yamashkin, A.A., Shchennikov, V.N., Erofeev, V.T., Osipov, A.K. \& Grishakov, G.V. (eds.): Thirty-third Readings in honor of N.P. Ogarev. Natural and engineering sciences. Publisher of the Mordovia State University, Saransk, pp. 15-18 [In Russian].

Rossi, G., Orsenigo, S., Montagnani, C., Fenu, G., Gargano, D., Peruzzi, L., Wagensommer, R.P., Foggi, B., Bacchetta, G., Domina, G., Conti, F., Bartolucci, F., Gennai, M., Ravera, S., Cogoni, A., Magrini, S., Gentili, R., Castello, M., Blasi, C. \& Abeli, T. 2015. Is legal protection sufficient to ensure plant conservation? The Italian Red List of policy species as a case study. Oryx. Available on CJO2015.

Seregin, A.P. 2012: Flora of Vladimir Oblast, Russia: checklist and atlas. Grif i K, Tula, 620 pp. [In Russian].

Seregin, A.P. 2014: Flora of Vladimir Oblast, Russia: grid data analysis. KMK Scientific Press Ltd., Moscow, 441 p. [In Russian].

Shcherbakov, A.V. 1999: Atlas of waterbodies' flora of Tula region. Russkiy universitet, Moscow, 45 pp. [In Russian].

Silaeva, T.B. (ed.). 2003: Red Book of the Republic of Mordovia: Rare species of plants, lichens and fungi. Mordovia Book Publishing House, Saransk, 288 pp. [In Russian].

Silaeva, T.B. 1981: About several new and rare species of the flora of Mordovia. Bulletin Moskovskogo obshchestva ispytateley prirody. Otdel biologicheskiy 86(5): 98-102 [In Russian].

Silaeva, T.B., Ageeva, A.M., Barmin, N.A., Kiryukhin, I.V., Pismarkina, E.V., Smirnov, V.M. \& Chugunov, G.G.. 2004: Rare plants and fungi: materials for maintenance of the Red Book of the Republic of Mordovia for 2004. Publisher of the Mordovia State University, Saransk, 48 pp. [In Russian]. 
Silaeva, T.B., Kiryukhin, I.V., Pismarkina, E.V., Ageeva, A.M., Barmin, N.A., Vargot, E.V., Smirnov, V.M. \& Chugunov, G.G. 2005: Rare plants and fungi: materials for maintenance of the Red Book of the Republic of Mordovia for 2005. Publisher of the Mordovia State University, Saransk, 64 pp. [In Russian].

Silaeva, T.B., Kiryukhin, I.V., Pismarkina, E.V., Barmin, N.A., Chugunov, G.G., Ageeva, A.M., Vargot, E.V., Grishutkina, G.A. \& Smirnov, V.M. 2006: Rare plants and fungi: materials for maintenance of the Red Book of the Republic of Mordovia for 2006. Publisher of the Mordovia State University, Saransk, 68 pp. [In Russian].

Silaeva, T.B., Kiryukhin, I.V., Pismarkina, E.V., Barmin, N.A., Chugunov, G.G., Ageeva, A.M., Vargot, E.V., Grishutkina, G.A. \& Smirnov, V.M. 2007: Rare plants and fungi: materials for maintenance of the Red Book of the Republic of Mordovia for 2007. Publisher of the Mordovia State University, Saransk, 92 pp. [In Russian].

Silaeva, T.B., Kiryukhin, I.V., Pismarkina, E.V., Chugunov, G.G., Vargot, E.V., Ageeva, A.M., Smirnov, V.M. \& Khapugin, A.A. 2008 Rare plants and fungi: materials for maintenance of the Red Book of the Republic of Mordovia for 2008. Publisher of the Mordovia State University, Saransk, 102 pp. [In Russian].

Silaeva, T.B., Kiryukhin, I.V., Pismarkina, E.V., Chugunov, G.G., Ivoylov, A.V., Ageeva, A.M., Vargot, E.V. \& Smirnov, V.M. 2009: Rare plants and fungi: materials for maintenance of the Red Book of the Republic of Mordovia for 2009. Publisher of the Mordovia State University, Saransk, 64 pp. [In Russian].

Silaeva, T.B. Kiryukhin, I.V., Chugunov, G.G., Levin, V.K., Mayorov, S.R., Pismarkina, E.V., Ageeva, A.M. \& Vargot, E.V. 2010a: Vascular plants of the Republic of Mordovia (synopsis of flora). Publisher of the Mordovia State University, Saransk, 352 pp. [In Russian].

Silaeva, T.B., Kiryukhin, I.V., Chugunov, G.G., Ageeva, A.M., Vargot, E.V., Pismarkina, E.V., Khapugin, A.A., Bolshakov, S.Yu., Ivoylov, A.V. \& Smirnov, V.M. 2010b: Rare plants and fungi: materials for maintenance of the Red Book of the Republic of Mordovia for 2010.

Publisher of the Mordovia State University, Saransk, 48 pp. [In Russian].

Silaeva, T.B., Vargot, E.V., Khapugin, A.A., Chugunov, G.G., Ageeva, A.M., Bolshakov, S.Yu., Ivoylov, A.V., Grishutkin, O.G. \& Kiryukhin, I.V. 2011: Rare plants and fungi: materials for maintenance of the Red Book of the Republic of Mordovia for 2011. Publisher of the Mordovia State University, Saransk, 60 pp. [In Russian].

Silaeva, T.B., Vargot, E.V., Bolshakov, S.Yu., Khapugin, A.A., Chugunov, G.G., Ivoylov, A.V., Grishutkin, O.G., Kiryukhin, I.V. 2012: Rare plants and fungi: materials for maintenance of the Red Book of the Republic of Mordovia for 2012. Publisher of the Mordovia State University, Saransk, 80 pp. [In Russian].

Silaeva, T.B., Vargot, E.V., Khapugin, A.A., Ageeva, A.M., Ivoylov, A.V., Kiryukhin, I.V., Pismarkina, E.V. \& Chugunov, G.G. 2013: Rare plants and fungi: materials for maintenance of the Red Book of the Republic of Mordovia for 2013. Publisher of the Mordovia State University, Saransk, 152 pp. [In Russian].

Silaeva, T.B., Vargot, E.V., Khapugin, A.A., Urbanavichyus, G.P., Urbanavichene, I.N., Ageeva, A.M., Ivoylov, A.V., Chugunov, G.G. \& Kiryukhin, I.V. 2014: Rare plants and fungi: materials for maintenance of the Red Book of the Republic of Mordovia for 2014. Publisher of the Mordovia State University, Saransk, 92 pp. [In Russian].
Silaeva, T.B., Vargot, E.V., Khapugin, A.A., Bolshakov, S.Yu., Ivoylov, A.V., Grishutkin, O.G., Grishutkina, G.A., Kiryukhin, I.V., Chugunov, G.G., Puzyrkina, M.V. \& Semchuk, A.A. 2015: Rare plants and fungi: materials for maintenance of the Red Book of the Republic of Mordovia for 2015. Publisher of the Mordovia State University, Saransk, 140 pp. [In Russian].

Stroh, P.A., Leach, S.J., August, T.A., Walker, K.J., Pearman, D.A., Rumsey, F.J., Harrower, C.A., Fay, M.F., Martin, J.P., Pankhurst, T., Preston, C.D. \& Taylor, I. 2014: A Vascular Plant Red List for England. Botanical Society of Britain and Ireland, Bristol, 184 pp.

Suško, U. 2008: Najas tenuissima, a new macrophyte species in flora of the Baltic Countries. Bot. Lithuanica 14: 65-67.

Terschuren, J. 1999: Action plan for Cypripedium calceolus in Europe. Nature Environ. 100: 5-56.

The Plant List. 2013: Version 1.1. Retrieved 24 March 2016 from http://www.theplantlist.org/

Thiers, B. 2015: Index Herbariorum: A global directory of public herbaria and associated staff. New York Botanical Gardens Virtual Herbarium. Available from: http://sweetgum.nybg.org/ih/

Tomović, G., Vukojičić, S., Niketić, M. \& Lakušić, D. 2007: New chorological data on some threatened and rare plants in Serbia. Arch. Biol. Sci. 59(1): 63-73.

Tomović, G., Zlatković, B., Niketić, M., Perić, R., Lazarević, P., Duraki, Š., Stanković, M., Lakušić, D., Anačkov, G., Knežević, J., Szabados, K., Krivošej, Z., Prodanović, D., Vukojičić, S., Stojanović, V., Lazarević, M. \& Stevanović, V. 2009: Threat status revision of some taxa from "The Red Data Book of Flora of Serbia 1". Botanica Serbica 33(1): 33-43.

Vakhrameeva, M.G., Varlygina, T.I., Tatarenko, I.V. 2014: Orchids of Russia (biology, ecology and protection). KMK Scientific Press Ltd., Moscow. 437 pp. [In Russian].

Vargot, E.V., Khapugin, A.A., Chugunov, G.G., Ivashina, A.A., Silaeva, T.B. \& Kiryukhin, I.V. 2012: Additions to the flora of Mordovia. Bulletin Moskovskogo obshchestva ispytateley prirody. Otdel biologicheskiy 117(3): 73-74 [In Russian].

Wróblewska, A., Brzosko, E. 2006: The genetic structure of the steppe plant Iris aphylla L. at the northern limit of its geographical range. Botanical Journal of the Linnean Society 152(2): 245-255.

Yamashkin, A.A. 1998: Physical and geographical conditions and landscapes of the Republic Mordovia. Publisher of the Mordovia State University, Saransk, 156 pp. [In Russian].

Yamashkin, A.A. (Ed.). 2012: Geographical atlas of Republic of Mordovia. Publisher of the Mordovia State University, Saransk, 204 pp. [In Russian]. 